\title{
The Interaction of GDP Growth Rate and FDI in Service Sector - Case of Croatia
}

\author{
Mario Pečarića, Tino Kusanovićb ${ }^{b}$ Antoni Šitum
}

Croatia is characterised by a foreign direct investment (FDI) inflow, mainly in the service sector, which is partly understandable owing to the country's orientation towards tourism. On the other hand, theoretical and empirical research indicates a weak impact of FDI in the service sector on the economic growth of the recipient country. Following the theoretical framework and critical analysis of previous research, the paper, on the example of Croatia in the period q1/2000 - q3/2020, uses the VAR model to analyse the mutual influence of GDP growth rate and FDI in the service sector. The results show that the impact of the GDP growth rate on the FDI inflow into the service sector is more significant and longer lasting than vice versa. The paper emphasises the importance of the adopted growth model for the type of FDI inflows into the recipient country, which in this case is

\section{KEY WORDS}

$\sim$ FDI sectoral structure

$\sim$ Croatia

$\sim$ Service sector

$\sim$ VAR model

$\sim$ GDP growth

$\sim$ Real exchange rate

\author{
a. University of Split, Faculty of Economics, Business and Tourism, Split, Croatia \\ e-mail: mpecaric@efst.hr \\ b. University of Split, Department of Professional Studies, Split, Croatia \\ e-mail: tinok@oss.unist.hr \\ doi: 10.7225/toms.v10.n01.023 \\ This work is licensed under (cc) BY
}

Received on: Mar 11, 2021 / Revised on: Apr 10, 2021 / Accepted on: Apr 15, 2021 / Published: Apr 20, 2021 characterised by the appreciation of the real exchange rate as an indicator of the country's competitiveness, whose impact on FDI inflow into the service sector is positive and long lasting.

\section{INTRODUCTION}

Foreign direct investment (FDI) is the most significant form of international capital flows and, given its presumed macroeconomic characteristics, the most desirable. Namely, unlike other forms of international capital flows, it is less volatile and more developmentally acceptable, taking into account the spill-over effects for the recipient country. Apart from the total capital inflows, which is most often linked to the effect on the country's economic growth, there are few works linking the sectoral structure of foreign direct investment and the country's economic growth (Walsh and Yu, 2010., Kinoshita, 2011). The literature highlights the unequal impact on the GDP growth of different FDI sectoral structure. Thereby the inflow into the service sector is considered to have a weaker and often more negative impact on the economic growth of the recipient country than the inflow into the manufacturing sector (Mencinger, 2003). The reason for this is the fact that investments in the service sector generally have lower value added and weaker spill - over effects upon the entire economy of the recipient country. Namely, until the 1980s and the emergence of the endogenous growth models, it was difficult to explain the permanently positive GDP growth per capita. The endogenous growth models bypassed the problem of diminishing return on capital that is inherent in Solow's model by assuming that each additional unit of capital investment brings knowledge not only to the investing firm but to the economy as a whole. These investment-related knowledge spillovers have therefore been responsible for generating 
positive long-term growth rates. The idea that investment can lead to positive knowledge spill-over has subsequently been taken as a basis for modelling the long-term effects of foreign direct investment.

This paper aims at analysing the relationship between FDI in the service sector and economic growth in Croatia. The analysis of the mutual relationship is important in terms of choosing the theoretical framework for interpreting the relationship. Namely, the thesis of the paper is that the dominant FDI inflow into the service sector is a result of the growth model based on increased domestic absorption due to real exchange rate appreciation and can be explained through the concept of so-called Dutch disease.

Appreciation pressures on the real exchange rate of the domestic currency affect the creation of trade deficits and encourage FDI in the service sector, especially in tourism and other service activities. It is important to note that so far no explicit research has been done on the example of Croatia on the relationship between FDI sectoral structures and the movement of the real effective exchange rate.

Given the character of the relationship between the mentioned variables, and based on a critical analysis of previous research, the empirical part of the paper has been formed through the VAR model. The reason is that it provides insight into the strength and duration of the reaction of selected variables in the model as a result of the shock of one standard deviation of another variable in the model. The reduced form of the VAR model specifically investigates the interrelationships between economic growth and FDI in the service sector, as well as FDI in the service sector and the real effective exchange rate index. The results obtained by analyzsng the VAR model indicate a negative and persistent effect of the shock of the FDI inflow in the service sector on the GDP growth rate, with a reverse effect being observed in in the opposite case. Furthermore, the shock of appreciation of the real effective exchange rate leads, as expected, to an increased FDI inflow in the service sector. As an additional variable in the VAR model, the trade balance variable (in \% of GDP) hs been used as an indicator of the state of foreign trade, primarily based on the investment inflow into the service, not necessarily export-oriented (manufacturing) sector.

\section{LITERATURE REVIEW AND THEORETICAL UNDERPININGS}

As mentioned previously, the majority of papers analyse the relationship between total FDI inflow and GDP growth rate and some other economic variables (eg inflation, exports, imports, labor costs ...), while a limited number of surveys only implicitly relate the investment sectoral structure to the selected variables.

Thus, for example, Čičak and Sorić (2015), using the VAR model on the example of Croatia and other CEE countries, analyse the relationship between FDI inflows and GDP growth rates. The authors conclude that FDI mostly leads to a higher GDP growth rate, which is especially evident in the example of Poland, the Czech Republic, and Hungary, while in the case of Latvia and Slovenia the opposite thesis is confirmed on the impact of GDP growth rate on the increased total FDI inflow. Furthermore, Dritsaki and Stiakakis (2014) also use the example of Croatia to analyse and test the relationship between FDI inflow, export and GDP growth rate. The authors conclude that there is a negative correlation between GDP growth rate and FDI inflow in the short and long term, i.e. that the inflow of investments does not lead to an increase in economic growth in Croatia. On the other hand, the authors show that there is a strong, significant, and reciprocal link between exports and GDP growth.

Ivanović (2015) also analyses the impact of FDI inflow on domestic investments, i.e. on investment activity, on the example of Croatia. Using the variables of GDP growth rate, domestic investments (in fixed capital) and changes in inventories, the author comes to the conclusion that foreign investments, with a time lag, have a negative impact on domestic investments. A similar conclusion is reached by Bilas (2019) who, in the case of Croatia, uses quarterly data for the period 2000 - 2019 to analyse the relationship between FDI and GDP growth rates in Croatia. Using cointegration tests, as well as the Granger causality test, the author shows that there is no long-term relationship between GDP growth rate and FDI inflow and that there is no Granger causality of the subject variables, which means that FDI has no significant impact on GDP growth in Croatia.

Perić and Nikšić Radić (2016), on the example of Croatia, analyse the impact of the total FDI inflow in the tourism sector (according to the stock approach) and the number of tourist arrivals in Croatia for the period 2000 - 2012, using quarterly data. The authors confirm the thesis on the causality of the inflow of investments into the tourism sector and the number of tourist arrivals in Croatia at the level of significance of $1 \%$.

Before the econometric testing of the hypothesis itself, as well as the explanation of the description of the variables that will be used in the testing of the hypothesis, the theoretical framework determining set hypothesis will be briefly presented. In the pre-crisis period (before 2008.) Croatia recorded a strong increase in real estate prices, accompanied by the expansion of construction and real estate, but which in turn contributed to the neglect of technological development, investment, employment and value added in the production and export activities with higher added value (Ivanov, 2015). While at the same time other transition countries have increased investment and efficiency in the manufacturing industry (especially Romania, Slovakia, the Czech Republic, Hungary, and Slovakia), Croatia has doubled its investment in construction more than others. Seen from today's perspective, it was a phenomenon that Neary and Corden (1982) 


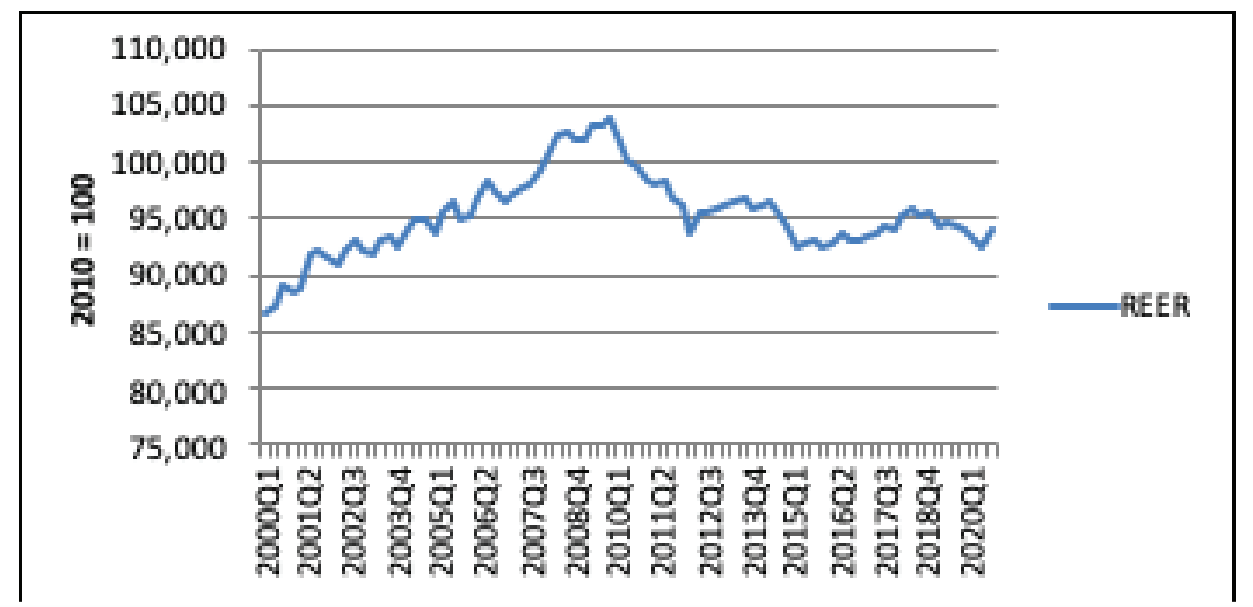

Figure 1.

Movement of the real effective exchange rate index, Q1/2000 - Q3/2020.

Source: BIS exchange rate database.

Figure 1 shows a constant upward trend of real exchange rate appreciation as of the last quarter of 2009, with the value of the index reaching 103.92, after which, due to the economic crisis and the consequent internal devaluation, there is a downward trend in the index, i.e. gradual depreciation of the real exchange rate. Following the graph above, it is interesting to note the trends in the movement of the three basic groups of FDI sectoral structure in the total FDI, over the observed time period, as shown on the chart below.
Figure 2 shows that, except for the very beginning of the 2000s, throughout the observed period there was a constant decline in the share of manufacturing FDI in total FDI inflow in Croatia, with this share literally halved, from the initial 30 per cent at the beginning of the observed period to only 15 per cent at the end of 2020. The share of service and financial sector FDI, on the other hand, increased slightly throughout the observed period, i.e. remained at the level of 30-35 per cent of the share in the total FDI inflow.

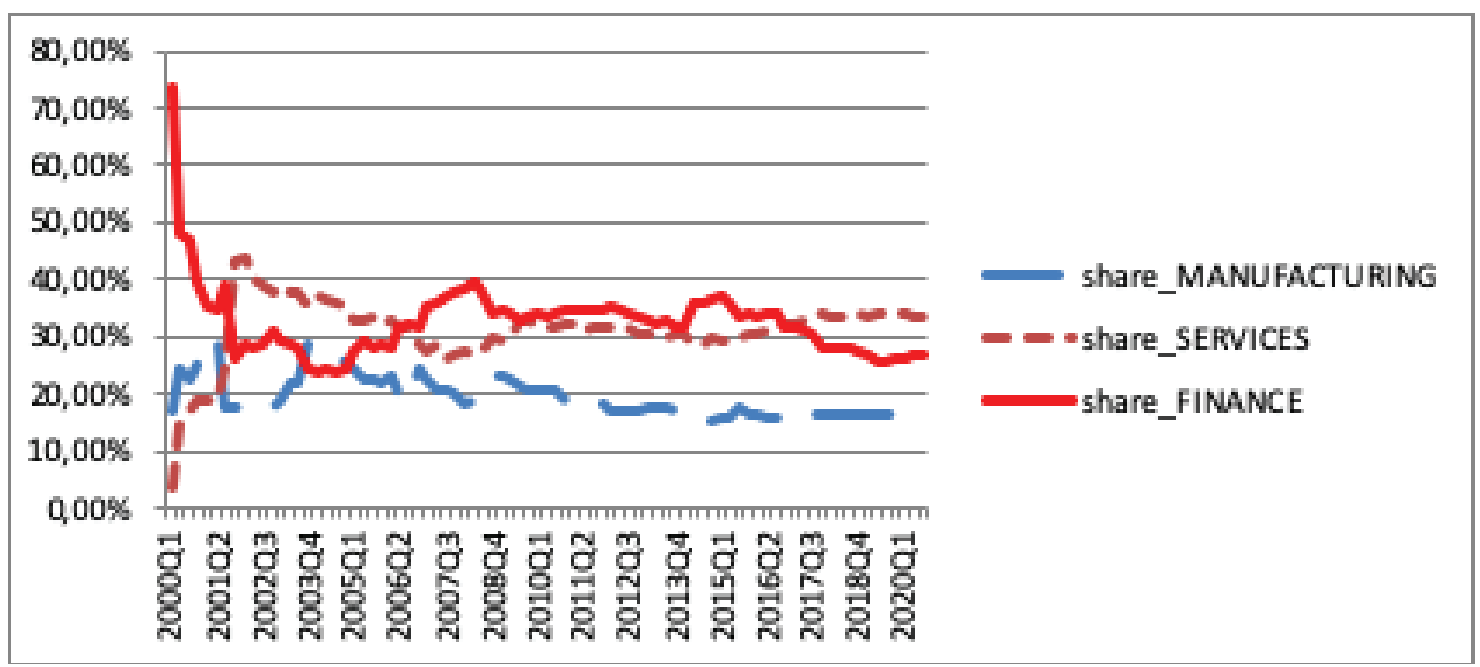

Figure 2.

Share of sectoral FDI in total FDI inflow, Q1/2000 - Q3/2020.

Source: CNB, Foreign direct investment database. 


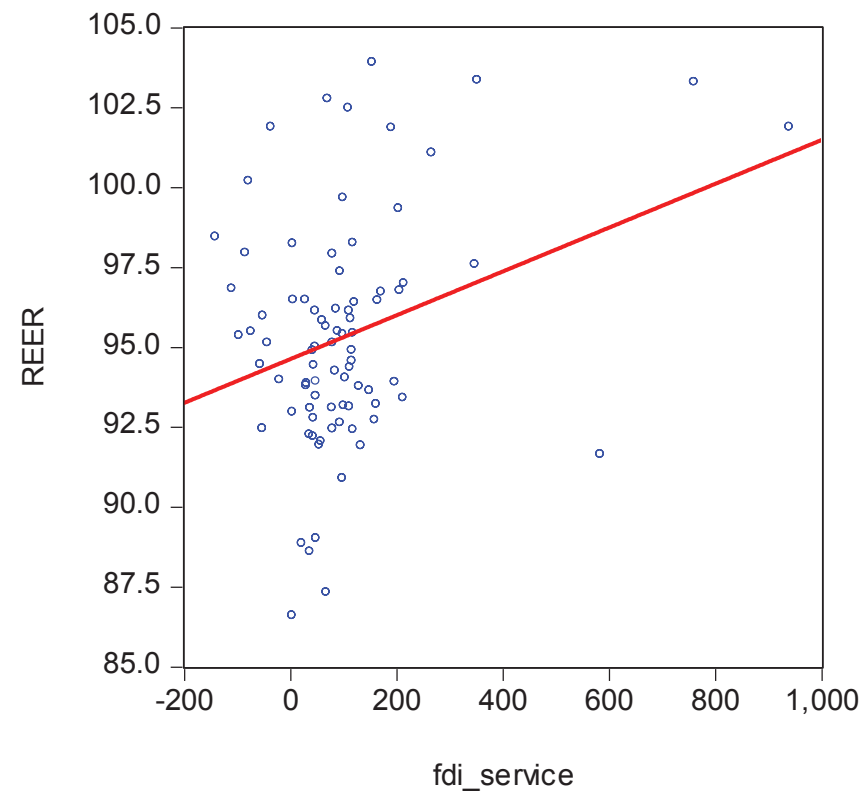

Figure 3.

Relationship between the REER index and the FDI inflow into the service sector.

Source: Author (E-views 7).

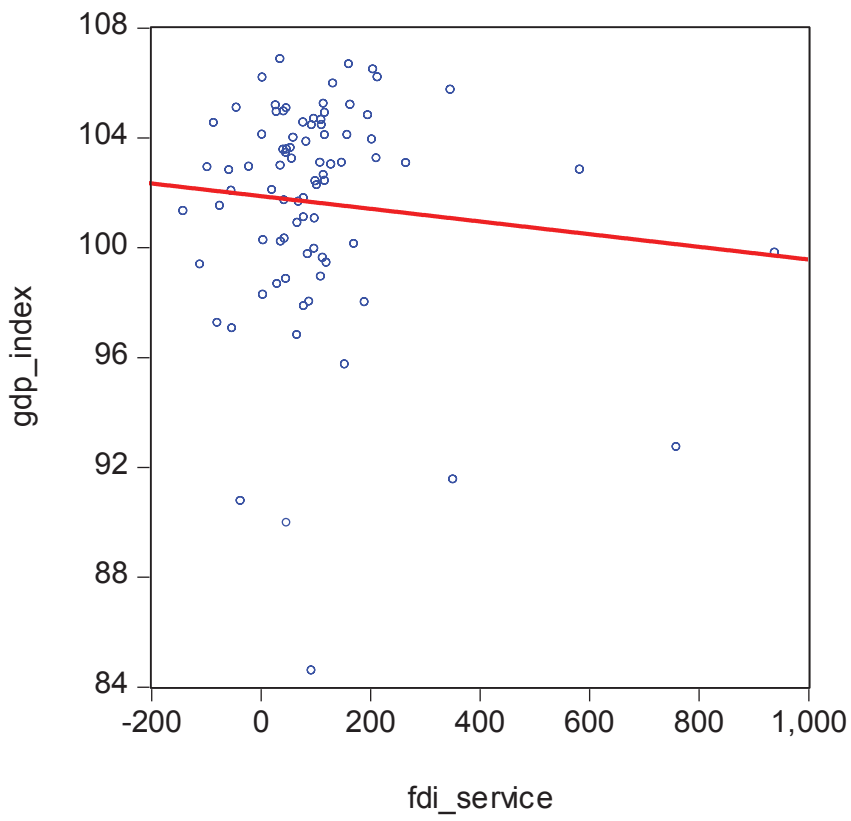

Figure 4.

Relationship between the GDP growth rate index and FDI inflow into the service sector.

Source: Author (E-views 7).
The focus of our empirical analysis will be on the relationship between FDI inflow into the service sector and GDP growth rate. The impact of movements of the real effective exchange rate on the investment inflow into the service sector will also be considered, where it is assumed that the appreciation of the real exchange rate will lead to a higher inflow into the service sector, while the relationship between GDP growth and investment inflow in the service sector assumes a slightly negative attitude (investments in the service sector are generally not exportoriented, and therefore do not lead to the improvement of the foreign trade position of the recipient country but to the exploitation of domestic absorption), as shown by the following figures.

\subsection{VAR Model}

In the following chapter, an analysis of the interrelationships of selected variables using vector autoregression will be performed in order to determine the impulse response functions of FDI inflow into service sector as a result of changes in the real effective exchange rate index and GDP growth rate. As a part of econometric testing, a VAR model was developed. Based on the vector autoregression model, impulse response functions of FDI inflow into the service sector have been developed as a result of changing the real exchange rate variable by one standard deviation. As additional variables in the model, in addition to the variable of the real effective exchange rate, the variable of the trade balance (in \% of GDP) and the variable of the GDP growth rate (in indices, corresponding period last year $=100$, quarterly data) will also be used. (both variables have been obtained from WIIW monthly database). The trade balance variable is used to examine the effects of GDP growth rate, real exchange rate movements and inflows into the service sector, assuming the negative effects of these variables on the trade balance. Based on the estimated VAR model, the impulse response functions have been determined, as shown below in the form of a graph. Complete VAR model calculations are presented in the Appendix.

Before statistical analysis is undertaken, selected time series have also been tested for the existence of a unit root, whereby the existence of a unit root has been determined for the variable of the real effective exchange rate, and consequently the first differences of the original observations should be used in further analysis. Furthermore, using the same test, the existence of a unit root in the time series of service sector FDI has not been confirmed. For the other variables used in the model, tests for the existence of a unit root have confirmed the non-stationarity of the data and therefore, according to Bahovec and Erjavec (2009), the first differences of the variables must be used in the model. However, in this paper, using the VAR model, the main goal is to show exclusively dynamic responses of variables to unexpected shocks in other variables. Since the task of analysis in this paper 
is not to estimate the parameters per se but to observe the same dynamic responses, the variables of the subject VAR model are also non-stationary (e.g., Perera (2017), using non-stationary variables, as suggested by Sims (1980) and Sims, Stock and Watson (1990)). Therefore in further analysis raw data of variables are used.

Accumulated Response to Cholesky One S.D. Innovations \pm 2 S.E.

Accumulated Response of USLUGE to REER

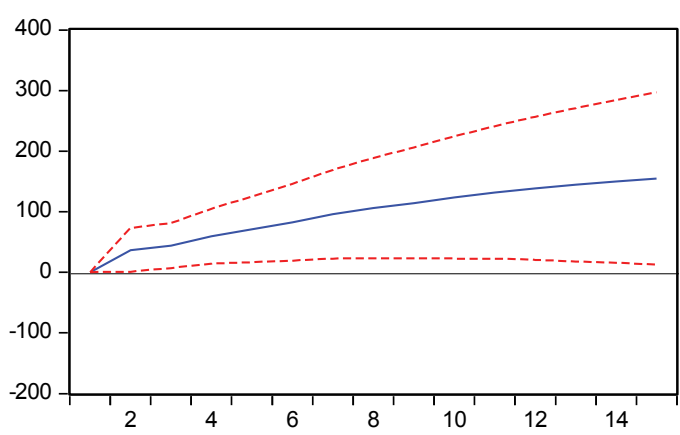

Accumulated Response of REER to USLUGE

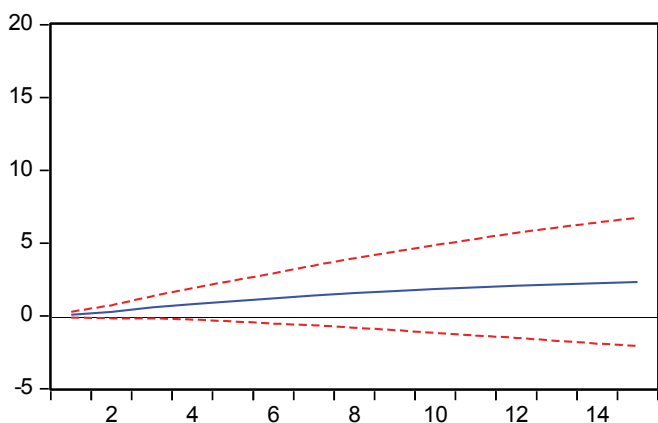

Accumulated Response of USLUGE to GDP INDEX

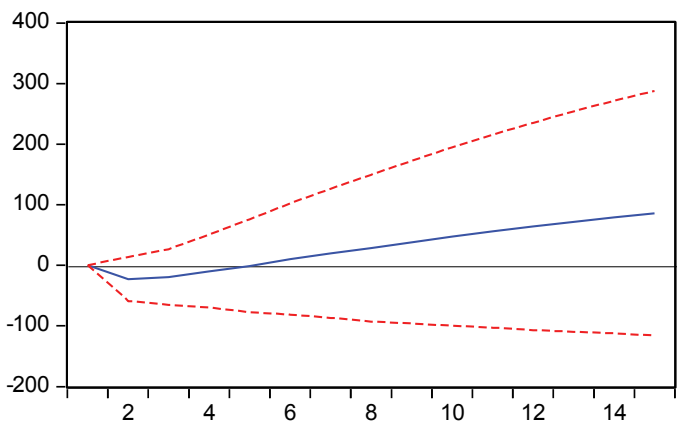

Accumulated Response of REER to GDP_INDEX

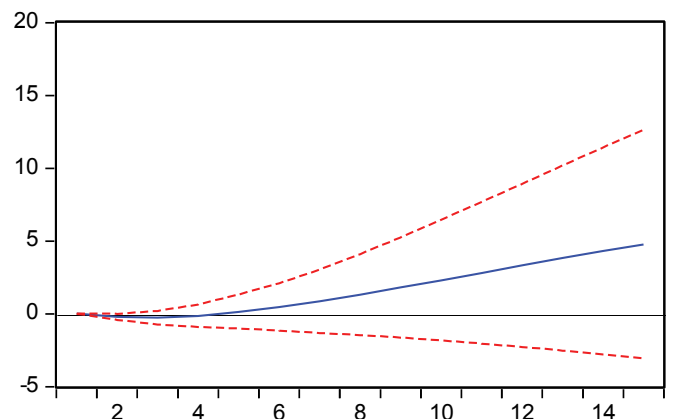

Accumulated Response of BALANCE_GOODS_AND_01 to USLUGEAccumulated Response of BALANCE_GOODS_AND_01 to REER
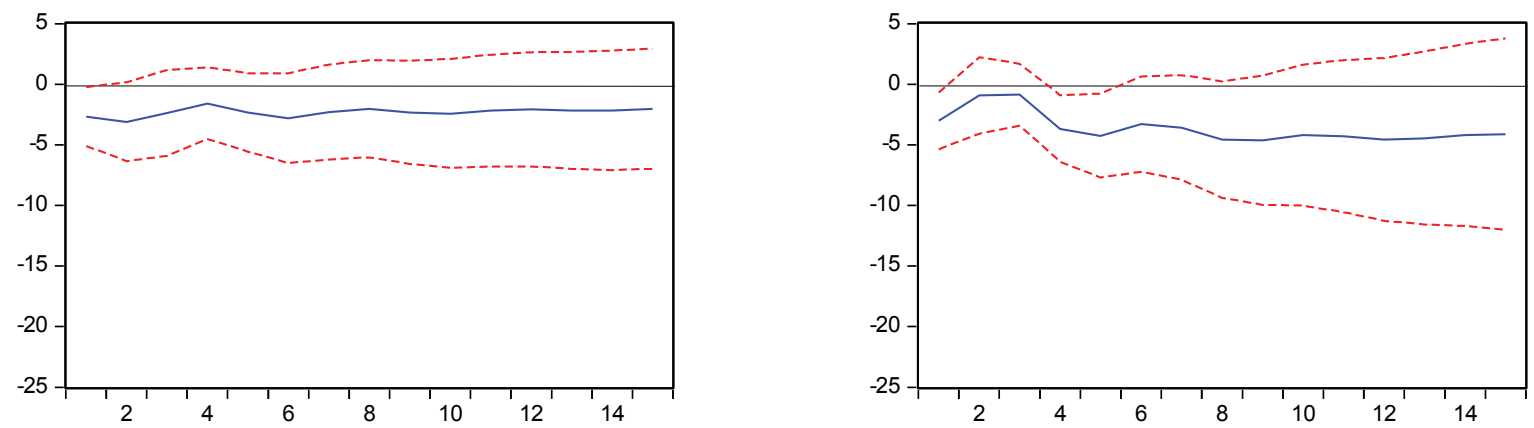

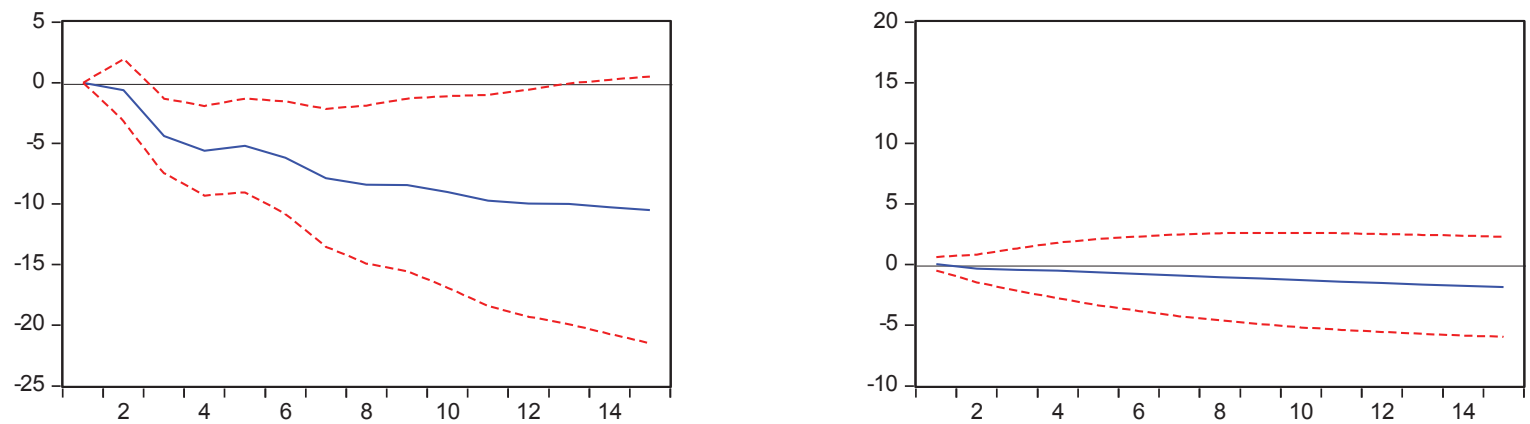

Accumulated Response of GDP_INDEX to REER

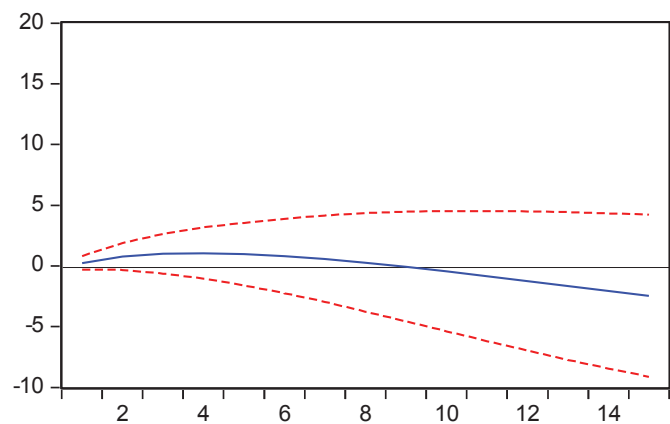

Figure 5.

Influence of shock from one standard deviation in the variable REER, GDP_INDEX and SERVICES (USLUGE) on other variables of the model (impulse response function) over a period of 15 quarters.

The impulse response functions as shown above, based on the VAR model, confirm the theoretically grounded settings of the work. Namely, as theoretically elaborated in the previous part of the paper, the shock of appreciation of the real effective exchange rate leads to an increased inflow of foreign investments in the service sector, and it is important to note that in the opposite case the shock of FDI into the service sector leads to appreciation of the real exchange rate, although to a lesser extent than in the previous case. Furthermore, the positive and long-term impact of the GDP variable shock on the FDI into the service sector is noticeable, with this impact becoming positive only at the end of the sixth quarter. Regarding the impact of theFDI in the service sector, there is a noticeable continuous negative impact on the GDP growth rate variable. This supports the previously elaborated thesis on the weak, if not negative impact of investment in the service sector on GDP. Also, the VAR model analysis presents the negative impact of the shock of the GDP growth rate and the inflow in service sector on the trade balance. Namely, as can be seen from the above graphs, the increase in the GDP growth rate and the appreciation of the real exchange rate lead to a persistent negative effect on the trade balance. The reason for this lies in the fact that an increase in the GDP growth rate leads to an increase in domestic absorption and, consequently, to a deterioration in the trade balance due to increased demand for imports. It is clear that the inflow in the service sector does not necessarily lead to a significant improvement in foreign trade in goods and services.

\section{CONCLUDING REMARKS}

The paper presents theoretical and empirical insights of the relationship between the exchange rate, GDP growth rate and FDI in the service sector in Croatia using VAR model. The analysis has confirmed the theoretically based assumptions of the paper. The positive and long-term impact of the GDP variable shock on the inflow into the service sector is noticeable, with this impact becoming positive only with a time lag of several quarters. In conclusion, the analysis confirmed the negative and persistent impact shock of the FDI in service sector on the GDP growth 
variable. This supports the thesis of a weak, if not negative impact of investment in the service sector on GDP, mainly due to the orientation of this type of investment to the exploitation of domestic absorption and less to the orientation towards the export of tangible goods, such as VAR model has shown (inflow of investment into the service sector leads to a negative and long-lasting effect on the trade balance).

Furthermore, a positive and long-term impact of the real exchange rate shock on the inflow of direct investments into the service sector has been found, with the reverse impact being weaker. The reason for this can be found in Bukovšak, et. al (2017) who conclude that not all capital flows equally affected the appreciation of the domestic currency, where the authors state the importance of other private capital flows (portfolio and debt capital) as one of the factors of exchange rate appreciation, which in this paper are not considered as a separate variable. In the opposite case, the shock of FDI into the service sector also leads to an appreciation of the real exchange rate (to a lesser extent than in the previous case).

The results of the VAR model confirm the developmental limitations of the Croatian growth model based on capital inflows into the tourism and construction sectors. The aim of the paper has been to indicate and explain the transmission link between FDI inflows into the service sector, GDP growth rate and the real effective exchange rate. The future research should be focused on the reform of economic model, which is beyond the scope of this paper.

\section{REFERENCES}

Bahovec, V., Erjavec, N., 2009. Uvod u ekonometrijsku analizu, 1. Izdanje, Element d.o.o., Zagreb.

Bilas, V., 2020. Examining the Relationship Between Foreign Direct Investment and Economic Growth: Evidence from Croatia. Montenegrin Journal of Economics, 16(2), pp.117-129. Available at: http://dx.doi.org/10.14254/1800-5845/2020.16-2.9.

Bukovšak, M., Lukinić Čardić, G. and Ranilović, N., 2017. Structure of Capital Flows and Exchange Rate: The Case of Croatia, Working Papers 52, The Croatian National Bank, Croatia.

Corden, W.M. \& Neary, J.P., 1982. Booming Sector and De-Industrialisation in a Small Open Economy. The Economic Journal, 92(368), p.825. Available at: http://dx.doi.org/10.2307/2232670.
Čičak, K. \& Sorić, P., 2015. The Interrelationship of FDI and GDP in European Transition Countries. The International Journal of Management Science and Business Administration, 1(4), pp.41-58. Available at:

http://dx.doi.org/10.18775/ijmsba.1849-5664-5419.2014.14.1003.

Dritsaki, C. \& Stiakakis, E., 2014. Foreign Direct Investments, Exports, and Economic Growth in Croatia: A Time Series Analysis. Procedia Economics and Finance, 14 pp.181-190. Available at: http://dx.doi.org/10.1016/s2212-5671(14)00701-1.

Ivanov, M., 2015. Efekti intervalutarnih odnosa na razvoj gospodarstva Hrvatske, radna verzija rada prezentiranog na skupu. Uloga regulatora u razvoju gospodarstva Hrvatske - 50.simpozij HZRFD.

Ivanović, I., 2015. mpact of foreign direct investment (FDI) on domestic investment in Republic of Croatia. Review of Innovation and Competitiveness, 1(1), pp.137-160. Available at:

http://dx.doi.org/10.32728/ric.2015.11/8

Kinoshita, Y., 2011. Sectoral Composition of Foreign Direct Investment and External Vulnerability in Eastern Europe. IMF Working Papers, 11(123), p.1. Available at: http://dx.doi.org/10.5089/9781455263400.001.

Magud, N. and Sosa, S., 2013. When And Why Worry About Real Exchange Rate Appreciation? The Missing Link Between Dutch Disease And Growth. Journal of International Commerce, Economics and Policy, 04(02), p.1350009. Available at: http://dx.doi.org/10.1142/s1793993313500099.

Mencinger, J., 2003. Does Foreign Direct Investment Always Enhance Economic Growth? Kyklos, 56(4), pp.491-508. Available at:

http://dx.doi.org/10.1046/j.0023-5962.2003.00235.x.

Perera, W.S.N., 2017. Credit Intensity of Economic Growth - A Sectoral Analysis: Case of Sri Lanka. Staff Studies, 47(1), p.1. Available at: http://dx.doi.org/10.4038/ss.v47i1.4701.

Perić, J. \& Radić, M.N., 2016. FDI-led tourism growth hypothesis: empirical evidence from Croatian tourism. European Journal of Tourism, Hospitality and Recreation, 7(3), pp.168-175. Available at:

http://dx.doi.org/10.1515/ejthr-2016-0019.

Sims, C.A., 1980. Macroeconomics and Reality. Econometrica, 48(1), p.1. Available at: http://dx.doi.org/10.2307/1912017.

Sims, C. A., Stock, J. A. and Watson, M. W., 1990. Inference in linear time series models with some unit roots, Econometrica: Journal of the Econometric Society 58, pp. 113 144. Available at: https://doi.org/10.2307/2938337.

Walsh, J. P. and Yu, J., 2010. Determinants of Foreign Direct Investment: A Sectoral and Institutional Approach, IMF Working Paper 10(187), pp. 1. Available at: https://doi.org/10.5089/9781455202218.001. 